\title{
Website to Facilitate Public Participation in Federal Rulemaking Process
}

On 23 January, the US Government introduced a new website-www.regulations. gov-that, according to the site's homepage, will make it easier for individuals "to participate in Federal rulemaking-an essential part of the American democratic process." This new, easy-to-use website may make it significantly easier for citizens concerned with animal welfare to learn about new regulations on the care and use of laboratory animals, and to respond to them quickly and effectively.

The new website contains descriptions of every proposed and final Federal regulation currently open for comment and published in the Federal Register. Visitors can read the full text of the regulations, and submit their comments through this website, to the Federal agencies responsible for the rulemaking action. Visitors can

\section{Regulation Update}

European Parliament Bans Animal Testing for Cosmetic Products

On 15 January, the European Parliament approved a conciliation agreement between Parliament and Council on Cosmetics for banning animal testing for cosmetic products ${ }^{2}$. This ban on animal testing and sales would start immediately where alternative non-animal tests are available, and will be followed by a complete ban six years after the directive becomes effective. After that time the use of animals in the testing of cosmetic products will end, but without jeopardizing consumer safety since alternative tests will have been developed. The other main points of the agreement reached in conciliation are:

- "A test and marketing ban will come into effect six years after the entry into force of the directive, i.e. 2009 , for the large majority of tests;

- "For those three tests for which there are no alternatives yet under consideration a marketing ban shall come into effect within ten years after entry into force, i.e. 2013;

- "Any prolongation of the 2013 deadline will be decided by codecision between Council and Parliament;

- "Alternative methods of testing shall be validated and adopted at the Community level 'with due regard to the development of validation within the OECD';

- "A ban on certain substances classified as carcinogenic, mutagenic or toxic for reproduction;

- "The qualitative and quantitative composition of the cosmetic product as well as information on undesirable effects on human health should be easily accessible to the public; and

- "Enhanced labeling requirements for substances which may cause allergic reactions2."

The ban must now to be approved by the 15 European Union member states, a likely formality following the November 2002 compromise, which saw the parliament back down on an immediate end to the animal testing ${ }^{3}$.

submit comments on specific documents, or submit a comment directly to the agency through the PDF or HTML version.

Participating government agencies include the Department of Agriculture (USDA), the Environmental Protection Agency (EPA), the Federal Comm unications Commission (FCC), the Government Services Administration (GSA), the Department of Health and Human Services (HHS), the Department of Labor (DOL), the Department of Transportation (DOT), and the National Archives and Records Administration (NARA).

More than 4,000 new rules a year are generated by some 160 federal agencies implementing Congressional laws. The expected capacity of this new site is at least 2,000 users at a time, or 16,000 comments per hour ${ }^{1}$.

\section{References}

1. Skrzycki, C. U.S. opens online portal to rulemaking. washingtonpost.com. (23 January 2003). http://www.washingtonpost.com/wpdyn/articles/A30469-2003Jan22.html.

2. Roth-Behrendt, D. At long last-agreement on cosmetic products. Report on the joint text approved by the Conciliation Committee for a European Parliament and Council directive of the European Parliament and of the Council amending Council Directive $76 / 768 / E E C$ on the approximation of the laws of the Member States relating to cosmetic products. European Parliament Daily Notebook (15 January 2003). http://www2.europarl.eu.int.

3. EU Finally set for ban on animal testing in cosmetics. Agence France (Via Dialog Corp). (15 January 2003). 